\title{
Association between single-nucleotide polymorphisms and early spontaneous hepatitis $B$ virus e antigen seroconversion in children
}

\author{
Haruki Komatsu ${ }^{1,2^{*}}$, Jun Murakami ${ }^{3}$, Ayano Inui ${ }^{2}$, Tomoyuki Tsunoda ${ }^{2}$, Tsuyoshi Sogo ${ }^{2}$ and Tomoo Fujisawa ${ }^{2}$
}

\begin{abstract}
Background: The disease progression following hepatitis B virus (HBV) infection is associated with single-nucleotide polymorphisms (SNPs). However, the role of SNPs in chronic HBV infection in children remains unclear. Here, we investigate the association between SNPs and early spontaneous hepatitis B e antigen ( $\mathrm{HBeAg}$ ) seroconversion in children with chronic hepatitis B infection.
\end{abstract}

Methods: This was a retrospective cohort study. We genotyped seven SNPs in the following genes, interleukin (IL)-10 (rs1800871 and rs1800872), human leukocyte antigen (HLA)-DPA1 (rs3077), HLA-DPB1 (rs9277535), HLA-DQB2 (rs7453920), HLA-DQB1 (rs2856718), and IL28B (rs8099917), in patients with chronic HBV infection using PCR and sequencing. These variants were analyzed for an association with early HBeAg seroconversion in children.

Results: Of 225 Japanese patients with chronic hepatitis B virus infection (male/female: 105/120, median age at initial visit: 6 years; range 0-44 years), 52 achieved spontaneous HBeAg seroconversion at the age of 10 years or younger (G1: early seroconversion group), and 57 did not achieve spontaneous HBeAg seroconversion under the age of 20 years (G2: late or no seroconversion group). Of the seven SNPS, only the HLA-DPA1 SNP displayed a low $p$-value $(P=0.070)$, but not significant, to have early HBeAg seroconversion in the dominant model and in the allele model $(P=0.073)$ using the chi-square test. The association study found a low $p$-value, but not significant, to have early HBeAg seroconversion in the dominant model for HLA-DPA1 (genotype TC $+\pi$ vs. CC, $P=0.070$, odds ratio: 2.016, 95\% confidence interval: 0.940-4.323) using a logistic regression model.

Conclusion: Although the HLA-DPA1 SNP did not show a statistically significant association with early HBeAg seroconversion in this study, the HLA-DPA1 SNP might increase the likelihood of achieving early spontaneous HBeAg seroconversion in children.

Keywords: Hepatitis B virus, Single-nucleotide polymorphism, Human leukocyte antigen, IL28B, IL10, HBeAg, Seroconversion, Children, HLA-DP

\section{Background}

Although universal vaccination with the hepatitis B vaccine has been introduced in almost all countries, more than 260 million people are suffering from chronic hepatitis B virus (HBV) infection worldwide. Adults with chronic HBV infection have a 15 to $20 \%$ risk of dying from HBV-related liver disease such as liver cirrhosis or

\footnotetext{
* Correspondence: haruki-komatsu@chive.ocn.ne.jp

'Department of Pediatrics, Toho University, Sakura Medical Center, 564-1 Shimoshizu Sakura, Chiba 285-8741, Japan

2Division of Hepatology and Gastroenterology, Department of Pediatrics, Eastern Yokohama Hospital, Yokohama, Japan

Full list of author information is available at the end of the article
}

hepatocellular carcinoma (HCC) [1]. In contrast, during childhood and adolescence, 3 to $5 \%$ and 0.01 to $0.03 \%$ of patients with chronic HBV infection develop cirrhosis and HCC, respectively [2]. Although host factors (e.g., male sex, older age, Asian or African ancestry, and family history of HCC) and viral factors (e.g., higher viral load, HBV genotype, longer duration of infection, and co-infection with hepatitis $C$ virus, human immunodeficiency virus, or hepatitis D virus) are known risk factors for HCC [3], predicting which chronic HBV-infected children should be treated is difficult. The European guidelines for children with chronic HBV infection recommend basing the 
decision to start treatment on ALT levels, HBeAg positivity, HBV-DNA levels, liver histology, family history of HCC, co-existing liver disease, and the patient's treatment history [2]. In particular, $\mathrm{HBeAg-seroconversion} \mathrm{is}$ usually accompanied by the remission of liver disease and confers a favorable outcome in children as well as adults [4].

Single nucleotide polymorphisms (SNPs) are well known to affect disease progression following HBV infection. The cytokine production-induced cell-mediated antiviral immune response plays a crucial role in the control of viral infection. Genetic variants of cytokines such as interleukin (IL)-10 and tumor necrosis factor- $\alpha$ gene have been associated with the outcome of HBV infection [5-11]. Moreover, recent genome-wide association studies showed that genetic variants of human leukocyte antigen ( $H L A)-D P$ and $H L A-D Q$ are strongly associated with the outcome of HBV infection in adults from Japan, Korea, and China [12-21]. However, whether $H L A-D P$ and $H L A-D Q$ genetic variants influence the outcome of HBV infection in children remains unknown. In this study, we retrospectively evaluated the effect of genetic variants of $I L-10, H L A-D P, H L A-D Q$, and $I L-28 B$ on early spontaneous hepatitis $B$ e antigen (HBeAg) seroconversion in children with chronic HBV infection.

\section{Methods \\ Patients}

The present study was a retrospective study. The diagnosis of chronic HBV infection was based on the detection of serum hepatitis B surface antigen on 2 occasions at least 6 months apart. Moreover, the patients were regularly followed for the measurement of serum ALT levels, HBeAg, anti-HBe antibodies, and AFP levels every 6 months. Patients with a history of antiviral treatment for hepatitis B infection were excluded. All patients were negative for anti-HCV antibodies. Patients with autoimmune hepatitis, Wilson's disease, and primary sclerosing cholangitis were excluded. The co-infection of HBV and hepatitis D virus (HDV) is extremely rare in Japan. Therefore, the co-infection of HBV and HDV was not excluded. The study protocols were approved by the ethical committee of Eastern Yokohama Hospital (No. 2011025) and Tottori University (G141), and performed in accordance with the ethical guidelines of the 1975 Declaration of Helsinki. Written informed consent was obtained from all parents or legal guardians of children. In addition, we obtained written informed consent from each adult patient participating in this study.

\section{DNA extraction and SNPs analysis}

Whole blood or serum was used for DNA extraction. Briefly, genomic DNA was extracted from $1 \mathrm{~mL}$ of peripheral whole blood using a Puregene blood core kit (Qiagen, Hilden, Germany) or from $200 \mu \mathrm{L}$ of serum using a QIAamp DNA blood kit (Qiagen) according to the manufacturer's instructions. The DNA was eluted in $200 \mu \mathrm{L}$ of elution buffer. Seven SNPs, $I L-10$ (IL10-819: rs1800871), IL-10 (IL-10-592: rs1800872), HLA-DPA1 (rs3077), HLA-DPB1 (rs9277535), HLA$D Q B 2$ (rs7453920), HLA-DQB1 (rs2856718), and $I L-$ $28 B$ (rs8099917), were assessed in this study.

PCR was performed using a $50 \mu \mathrm{L}$ reaction mixture containing $25 \mu \mathrm{L}$ of AmpliTaq Gold 360 Master Mix (Applied Biosystems, Foster City, CA), 25 pmol of each primer, and $5 \mu \mathrm{L}$ of extracted DNA. When whole blood samples were used for PCR, a single-round PCR was performed. When serum samples were used for PCR, nested PCR was performed. The PCR amplification was performed using the following protocol: an initial precycle incubation of $95^{\circ} \mathrm{C}$ for $10 \mathrm{~min}$, followed by 40 cycles of denaturation at $95^{\circ} \mathrm{C}$ for $30 \mathrm{~s}$, annealing at $55^{\circ} \mathrm{C}$ for $30 \mathrm{~s}$, and extension at $72^{\circ} \mathrm{C}$ for $60 \mathrm{~s}$. Then, $1 \mu \mathrm{L}$ of the first PCR reaction product was reamplified with the inner primers for 40 cycles under the same reaction conditions used in the first-round PCR. The amplified PCR products were purified using a QIAquick gel extraction kit (QIAGEN) and then used for direct sequencing in the forward and reverse directions. Nested primer sets were synthesized to amplify each region. An internal primerpair was used for the single-round PCR amplification of DNA extracted from whole blood. The sequences of the PCR primers are shown in Table 1 . The levels of serum HBV DNA was measured by COBAS TaqMan HBV DNA test (detection range from 2.1 to $9.0 \log$ copies $/ \mathrm{mL}$ ).

\section{Statistical analysis}

To characterize the patients' background, statistical analyses were performed with StatMate IV for Windows (Advanced Technology for Medicine \& Science, Tokyo, Japan), Microsoft Office Excel 2007, and STATA/MP software (version 13.1; StataCorp, College Station, TX). Categorical variables and non-categorical variables were compared between groups using the Yates corrected chisquare test and Mann-Whitney $U$ test, respectively. The multivariate test is by maximum likelihood logistic regression (association of all of the factors with "Early" versus "Late or no" group). Moreover, all statistical analyses for SNPs were performed using SNPAlyze Ver.8 (DAYNACOM, Chiba, Japan). We tested the genotypic distributions for Hardy-Weinberg equilibrium (HWE) using the Yates corrected chi-square test. The difference between the case-control groups in terms of the distribution of genotypes was analyzed using the CochranArmitage trend test if HWE did not hold in the combined case-control population [22]. Logistic regression was performed for the comparison between the case 
Table 1 Primers for amplification and sequencing

\begin{tabular}{|c|c|c|c|}
\hline SNP ID & & & sequence (5 'to 3 ') \\
\hline \multirow{4}{*}{$\begin{array}{l}\text { IL-10-819 } \\
\text { (rs1800871) }\end{array}$} & External & forward & TCAACTTCTTCCACCCCATC \\
\hline & & reverse & GGCACATGTTTCCACCTCTT \\
\hline & Internal & forward & GGGTGAGGAAACCAAATTCTC \\
\hline & & reverse & TGCACTTGCTGAAAGCTTCTT \\
\hline \multirow{4}{*}{$\begin{array}{l}\text { IL-10-592 } \\
\text { (rs1800872) }\end{array}$} & External & forward & TGGAAACATGTGCCTGAGAA \\
\hline & & reverse & CAGTGACGTGGACAAATTGC \\
\hline & Internal & forward & AAAGGAGCCTGGAACACATC \\
\hline & & reverse & CCTTAGGTCTCTGGGCCTTA \\
\hline \multirow{4}{*}{$\begin{array}{l}\text { HLA-DPA1 } \\
\text { (rs3077) }\end{array}$} & External & forward & CTGAACTCCAGCTGCCCTAC \\
\hline & & reverse & CTCCCCGCTCTGAAATACTG \\
\hline & Internal & forward & AACTCCAGCTGCCCTACAAA \\
\hline & & reverse & GGATAAAAGGCTCAATGAAAGG \\
\hline \multirow{4}{*}{$\begin{array}{l}\text { HLA-DPB1 } \\
\text { (rs9277535) }\end{array}$} & External & forward & GGGCCTGTTACACATGACACT \\
\hline & & reverse & TGGATGCATTCAAAAGTCCA \\
\hline & Internal & forward & TGCCCCCAAATCAAGTTTAG \\
\hline & & reverse & TGGCACACAAAGAAAATGGT \\
\hline \multirow{4}{*}{$\begin{array}{l}\text { HLA-DQB2 } \\
\text { (rs7453920) }\end{array}$} & External & forward & ACGCGAAATTGAGTTCTTGG \\
\hline & & reverse & CAGGCATGGGTTTACTTGGT \\
\hline & Internal & forward & GGTAAGAGGGAAAGCCCAGT \\
\hline & & reverse & CTGTCTCCGAGATTCCCAAG \\
\hline \multirow{4}{*}{$\begin{array}{l}\text { HLA-DQB1 } \\
\text { (rs2856718) }\end{array}$} & External & forward & TTGGCCAGAGTATGCTTTCA \\
\hline & & reverse & TTGGCCTGAGGTCTATGCT \\
\hline & Internal & forward & TATGCTTTCACCAACTTCCTTCAC \\
\hline & & reverse & GAGCTCCCTCTGGCAGGTT \\
\hline \multirow{4}{*}{$\begin{array}{l}\text { IL-28B } \\
\text { (rs8099917) }\end{array}$} & External & forward & GTGCATATGTITTCTGAC \\
\hline & & reverse & GAGGCCCCTCACCCATGC \\
\hline & Internal & forward & AAGTAACACTTGTTCCTTGTAAAAGATTCC \\
\hline & & reverse & CGCTATAATTAAAGATGTGGGAGAATGCAA \\
\hline
\end{tabular}

group (G1: early seroconversion) and the control group (G2: late or no seroconversion). A p-value of 0.05 or less was considered statistically significant. The sample size estimation was calculated using $G^{*}$ Power 3.1.9.2 (http://www.gpower.hhu.de/) [23].

\section{Results}

Patient characteristics

Between 1981 and 2012, a total of 225 Japanese patients comprising children, adolescents, and mothers (male/ female: 105/120, age: $0-44$ years, median age: 6 years, follow-up period: $1-25$ years, median: 8 years) with chronic HBV infection were followed in the Pediatric
Departments of Eastern Yokohama Hospital and Tottori University Hospital. Of the 225 patients with chronic HBV infection, 115 achieved $\mathrm{HBeAg}$ seroconversion and 110 did not achieve HBeAg seroconversion during the follow-up period. Of the 115 patients with $\mathrm{HBeAg}$ seroconversion, 63 achieved $\mathrm{HBeAg}$ seroconversion at the age of 10 years or younger, 34 achieved HBeAg seroconversion between the ages of 11 and 19 years, and 18 achieved HBeAg seroconversion at the age of 20 years or older. Of the 110 patients without HBeAg seroconversion during the follow-up period, 67 were under the age of 20 years, and 43 were 20 years or older. Of the 63 patients who achieved HBeAg seroconversion at the age of 10 years or younger, 52 were available for evaluation and classified into the early seroconversion group (G1). Of the 18 patients who achieved $\mathrm{HBeAg}$ seroconversion at the age of 20 years or older, 16 were available for evaluation. Of the 43 patients without HBeAg seroconversion who were 20 years or older, 41 were available for evaluation. A total of 57 patients were classified into the late or no seroconversion group (G2). The classification scheme of the patients based on HBeAg seroconversion is shown in Figure 1.

The patients characteristics in individual groups were shown in Table 2. In G1, the sources of HBV infection were mother-to-child transmission $(\mathrm{n}=43)$, family contact $(n=5)$, unknown $(n=3)$, and blood transfusion $(\mathrm{n}=1)$. In G2, the sources were mother-to-child transmission $(\mathrm{n}=39)$, unknown $(\mathrm{n}=14)$, and family contact $(\mathrm{n}=4)$. Of the 57 patients belonging to $\mathrm{G} 2,37$ were HBV carrier mothers. Therefore, there was a significant difference in the sex ratio between G1 and G2. The levels of ALT at the initial visit were significantly higher in the G1 group than the G2 group. There was no significant difference in the duration of the follow-up period or HBV genotype between the G1 and G2 groups. At the last visit, 23 of 57 patients in the G1 were positive for serum HBV DNA and all of G2 patients were positive for serum HBV DNA. The levels of serum HBV DNA were 4.8 (median) $\log$ copies $/ \mathrm{ml}$ and 8.5 (median) log copies/ml in the G1 and G2, respectively. There was a statistical significance in age at initial visit, gender, ALT level at initial age, serum HBV DNA level at last visit, and mother-to-child transmission between G1 and G2 in univariate analysis. Multivariate analysis showed that a statistical significance between G1 and G2 was detected in gender, duration of the follow-up period, serum HBV DNA level, and mother -to-child transmission.

\section{Hardy-Weinberg equilibrium}

The HWE proportions are shown in Table 3. Of the 7 SNPs, 5 (IL-10-819: rs1800871, HLA-DPA1: rs3077, HLADPB1: rs9277535, HLA-DQB1: rs2856718, and IL28B: rs8099917) had genotype distributions that did not 


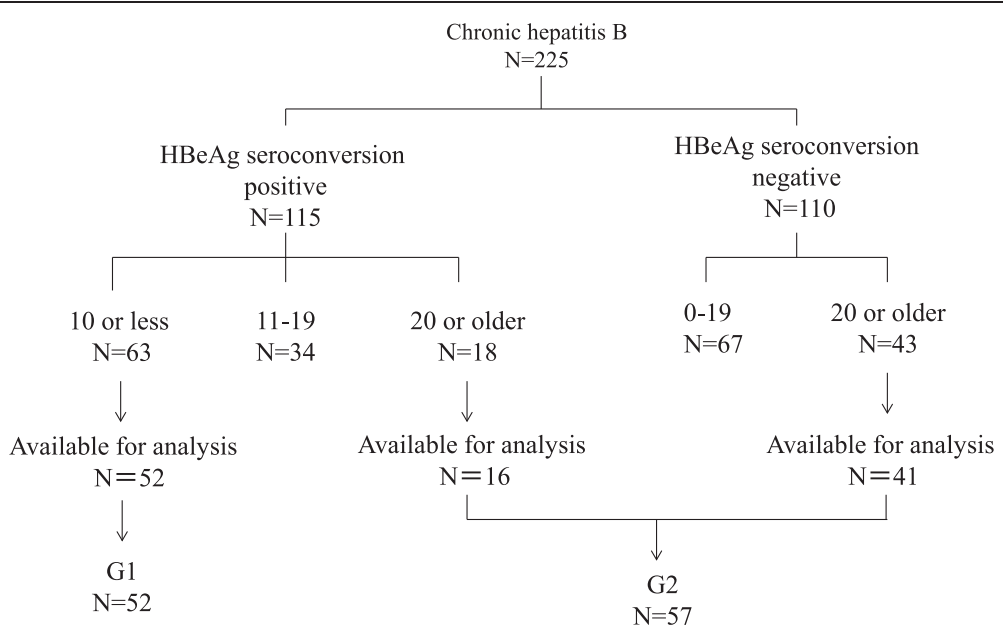

Figure 1 Classification of the subjects based on hepatitis B e antigen seroconversion.

significantly deviate from HWE $(p>0.05)$ in either G1 or G2. However, the remaining 2 SNPs showed a significant deviation in G1 and/or G2. These findings suggest that a chi-square test was inappropriate for the analysis of the case-control association for IL10-592 (rs1800872) and HLA-DQB2 (rs7453920).
Association between SNPs and $\mathrm{HBeAg}$ seroconversion None of the five SNPs that conformed to HWE expectations (IL-10-819: rs1800871, HLA-DPA1: rs3077, and HLA-DPB1: rs9277535, HLA-DQB1: rs2856718, and IL28B: rs8099917) had a significant association with early seroconversion in the dominant, recessive, allele,

Table 2 Patients characteristics in individual groups

\begin{tabular}{|c|c|c|c|c|c|}
\hline & & $\begin{array}{l}\text { G1: Early } \\
(\mathrm{N}=52)\end{array}$ & $\begin{array}{l}\text { G2: Late or no seroconversion } \\
(\mathrm{N}=57)\end{array}$ & Univariate & Multivariate \\
\hline & & & & $P$ value & $P$ value \\
\hline \multicolumn{2}{|l|}{ Age at initial visit (year) } & $\begin{array}{l}0-10 \\
\text { (Median 2.8) }\end{array}$ & $\begin{array}{l}0-44 \\
\text { (Median 28) }\end{array}$ & $<0.00005$ & $* * * *$ \\
\hline \multicolumn{2}{|l|}{ Gender (Male/Female) } & $28 / 24$ & $5 / 52$ & $<0.00005$ & 0.001 \\
\hline \multicolumn{2}{|l|}{ ALT level (IU/L) at initial visit } & $\begin{array}{l}\text { 10-725 } \\
\text { (Median 80.5) }\end{array}$ & $\begin{array}{l}\text { 7-767 } \\
\text { (Median 23) }\end{array}$ & $<0.00005$ & 0.489 \\
\hline \multicolumn{2}{|l|}{ Duration of follow-up period (year) } & $\begin{array}{l}\text { 1-21 } \\
\text { (Median 10.0)* }\end{array}$ & $\begin{array}{l}\text { 1-25 } \\
\text { (Median, 6.0) }\end{array}$ & 0.6218 & 0.013 \\
\hline \multicolumn{2}{|l|}{ Age at HBe seroconversion } & $\begin{array}{l}\text { 1-10 } \\
\text { (Median 6.5) }\end{array}$ & $\begin{array}{l}\text { 21-34 } \\
(\text { Median 25)** }\end{array}$ & Not done & Not done \\
\hline \multicolumn{2}{|l|}{$\begin{array}{l}\text { Serum HBV DNA level at } \\
\text { last visit (log copies } / \mathrm{mL} \text { ) }\end{array}$} & $\begin{array}{l}2.5-8.7 \\
\text { (Median } 4.8)^{* * *}\end{array}$ & $\begin{array}{l}3.0-9.0 \\
\text { (Median 8.5) }\end{array}$ & $<0.00005$ & 0.003 \\
\hline \multirow[t]{4}{*}{ Transmission route } & Mother-to-child & 43 & 37 & Mother-to-child & \\
\hline & Household contacts & 5 & 4 & v.s. Non Mother-to-child & \\
\hline & Blood transfusion & 1 & 0 & 0.036 & 0.016 \\
\hline & Unknown & 3 & 16 & & \\
\hline \multirow[t]{4}{*}{ HBV Genotype } & A & 0 & 1 & Genotype C & \\
\hline & B & 7 & 10 & v.s. Non genotype C & \\
\hline & C & 44 & 45 & 0.445 & 0.221 \\
\hline & $\mathrm{D}$ & 1 & 1 & & \\
\hline
\end{tabular}


Table 3 The results of the Hardy-Weinberg equilibrium proportions

\begin{tabular}{|c|c|c|c|c|c|}
\hline SNP ID & Genotype & $\begin{array}{l}\text { No. of G1 early } \\
\text { seroconversion genotype } \\
\text { frequency (\%) }\end{array}$ & $P$ value & $\begin{array}{l}\text { No. of G2 late or no } \\
\text { seroconversion genotype } \\
\text { frequency (\%) }\end{array}$ & $P$ value \\
\hline IL-10-819 & $\pi$ & $24(46.2)$ & & $25(43.9)$ & \\
\hline \multirow[t]{2}{*}{ (rs1800871) } & $C T$ & 18 (34.6) & 0.126 & 22 (38.6) & 0.3116 \\
\hline & CC & $10(19.2)$ & & $10(17.5)$ & \\
\hline IL-10-592 & $\mathrm{AA}$ & $23(44.2)$ & & $26(45.6)$ & \\
\hline \multirow[t]{2}{*}{ (rs1800872) } & CA & $14(26.9)$ & 0.003 & $21(36.8)$ & 0.221 \\
\hline & CC & 15 (28.8) & & $10(17.5)$ & \\
\hline HLA-DPA1 & CC & $22(42.3)$ & & 34 (59.6) & \\
\hline \multirow[t]{2}{*}{ (rs3077) } & $\mathrm{TC}$ & 27 (51.9) & 0.267 & $22(38.6)$ & 0.424 \\
\hline & $\pi$ & $3(5.8)$ & & $1(1.8)$ & \\
\hline HLA-DPB1 & GG & $27(51.9)$ & & $26(45.6)$ & \\
\hline \multirow[t]{2}{*}{ (rs9277535) } & $A G$ & $17(32.7)$ & 0.147 & $21(36.8)$ & 0.221 \\
\hline & $\mathrm{AA}$ & $8(15.4)$ & & $10(17.5)$ & \\
\hline HLA-DQB2 & GG & $43(82.7)$ & & $50(87.7)$ & \\
\hline \multirow[t]{2}{*}{ (rs7453920) } & GA & 0 & $1.736 \times 10^{-11}$ & $1(1.8)$ & $4.409 \times 10^{-10}$ \\
\hline & $\mathrm{AA}$ & $9(17.3)$ & & $6(10.5)$ & \\
\hline HLA-DQB1 & $\mathrm{AA}$ & 18 (34.6) & & 18 (31.6) & \\
\hline \multirow[t]{2}{*}{ (rs2856718) } & GA & $24(46.2)$ & 0.913 & $30(52.6)$ & 0.742 \\
\hline & GG & $10(19.2)$ & & $9(15.8)$ & \\
\hline IL-28B & $\pi$ & $39(75.0)$ & & $44(77.2)$ & \\
\hline \multirow[t]{2}{*}{ (rs8099917) } & GT & $10(19.2)$ & 0.176 & $13(22.8)$ & 0.752 \\
\hline & GG & $3(5.8)$ & & 0 & \\
\hline
\end{tabular}

and genotype models using the Yates corrected chisquare test (Table 4). However, weak associations with early $\mathrm{HBeAg}$ seroconversion were observed in the dominant model $(\mathrm{P}=0.070)$ and the allele model $(\mathrm{P}=0.073)$ for the $H L A-D P A 1$ SNP. In addition, the AIC value (IM: independent model - DM: dependent model) was $>0$ in both models for the HLA-DPA1 SNP (Table 3). Because an $\mathrm{AIC}$ value $>0$ indicates that a genetic polymorphism and a disease are dependent [24], the HLA-DPA1 SNP (rs3077) shows a tendency to have early spontaneous HBeAg seroconversion. The Cochran-Armitage trend test was used to evaluate the difference between the case and control groups (G1 vs. G2) in terms of the distribution of genotypes for the IL10-592 SNP and HLA-DQB2 SNP. However, neither of these SNPs showed a significant association (IL10-592; $\mathrm{P}=0.405, H L A-D Q B 2: \mathrm{P}=0.374)$.

A logistic regression model was also used to evaluate the association between SNPs and HBeAg seroconversion (Table 5). Although no statistically significant association between SNPs and early spontaneous HBeAg seroconversion was observed in the logistic regression model, the HLA-DPA1 SNP (rs3077) showed a low p-value to have early spontaneous $\mathrm{HBeAg}$ seroconversion in the dominant model (genotype TC + TT vs. CC, $\mathrm{P}=0.070$, odds ratio: $2.016,95 \%$ confidence interval: $0.940-4.323)$. Taken together, these findings suggest that the HLA-DPA1 SNP (rs3077) has a possibility to induce early spontaneous HBeAg seroconversion in children.

Because genotype GA of $H L A-D Q B 2$ (rs7453920) in G1 and genotype GG of $I L 28 B$ (rs8099917) in G2 were not detected, there are no data for the recessive model for $I L 28 B$ in Table 4, the genotype model for $H L A$ $D Q B 2$ in Table 5, or the recessive model and genotype model for $I L 28 B$ in Table 4.

\section{Discussion}

In this study, we evaluated retrospectively whether the genetic variants of $I L-10, H L A-D P, H L A-D Q$, and $I L-28 B$ could influence early spontaneous $\mathrm{HBeAg}$ seroconversion in children with chronic HBV infection. We thought that this SNP analysis needed 2 groups which had distinctly different phenotypes to archive a significant result. One is the early spontaneous $\mathrm{HBeAg}$ seroconversion group. The other is late or no $\mathrm{HBeAg}$ seroconversion group. Although there was no clinical significance of 10 and 20 of age, the patients with $\mathrm{HBeAg}$ seroconversion who are 10 or less of age were defined simply as "early $\mathrm{HBeAg}$ seroconversion" in order to obtain appropriate sample size of both groups. Initially, we compared the "early HBeAgseroconversion group (G1: $\mathrm{N}=52$ )" with the "no HBeAg- 
Table 4 Association between SNPs and HBeAg seroconversion using Akaike's information criteria and chi-square test

\begin{tabular}{|c|c|c|c|c|c|c|c|c|c|c|c|}
\hline \multirow[t]{3}{*}{ SNP ID } & \multicolumn{3}{|c|}{ Dominant model } & \multicolumn{3}{|c|}{ Recessive model } & \multicolumn{3}{|c|}{ Recessive model } & \multicolumn{2}{|c|}{ Genotype model } \\
\hline & \multirow{2}{*}{$\begin{array}{l}\text { AIC } \\
\text { (IM-DM) }\end{array}$} & \multicolumn{2}{|c|}{ Chi-squire test } & \multirow{2}{*}{$\begin{array}{l}\text { AIC } \\
\text { (IM-DM) }\end{array}$} & \multicolumn{2}{|c|}{ Chi-squire test } & \multirow{2}{*}{$\begin{array}{l}\text { AIC } \\
\text { (IM-DM) }\end{array}$} & \multicolumn{2}{|c|}{ Chi-squire test } & \multirow{2}{*}{$\begin{array}{l}\text { AIC } \\
\text { (IM-DM) }\end{array}$} & \multirow{2}{*}{$\begin{array}{l}\text { Chi-squire test } \\
P \text { value }\end{array}$} \\
\hline & & $P$ value & OR $(95 \% \mathrm{Cl})$ & & $P$ value & OR $(95 \% \mathrm{Cl})$ & & $P$ value & OR $(95 \% \mathrm{Cl})$ & & \\
\hline IL-10-819 & -1.942 & 0.810 & $\begin{array}{l}0.912 \\
(0.428-1.941)\end{array}$ & -1.948 & 0.820 & $\begin{array}{l}1.119 \\
(0.424-2.953)\end{array}$ & -1.998 & 0.963 & $\begin{array}{l}0.987 \\
(0.569-1.723)\end{array}$ & -3.808 & 0.909 \\
\hline \multicolumn{12}{|l|}{ (rs1800871) } \\
\hline HLA-DPA1 & 1.289 & 0.070 & $\begin{array}{l}2.016 \\
(0.940-4.325)\end{array}$ & -0.716 & 0.266 & $\begin{array}{l}3.429 \\
(0.345-34.042)\end{array}$ & 1.216 & 0.073 & $\begin{array}{l}1.743 \\
(0.946-3.211)\end{array}$ & -0.080 & 0.145 \\
\hline \multicolumn{12}{|l|}{ (rs3077) } \\
\hline HLA-DPB1 & -1.567 & 0.510 & $\begin{array}{l}0.777 \\
(0.366-1.650)\end{array}$ & -1.908 & 0.762 & $\begin{array}{l}0.855 \\
(0.309-2.362)\end{array}$ & -1.565 & 0.510 & $\begin{array}{l}0.828 \\
(0.471-1.453)\end{array}$ & -3.566 & 0.805 \\
\hline \multicolumn{12}{|l|}{ (rs9277535) } \\
\hline HLA-DQB1 & -1.887 & 0.736 & $\begin{array}{l}0.872 \\
(0.392-1.938)\end{array}$ & -1.777 & 0.636 & $\begin{array}{l}1.270 \\
(0.471-3.422)\end{array}$ & -1.999 & 0.976 & $\begin{array}{l}1.008 \\
(0.589-1.727)\end{array}$ & -3.509 & 0.782 \\
\hline \multicolumn{12}{|l|}{ (rs2856718) } \\
\hline $\mathrm{IL}-28 \mathrm{~B}$ & -1.928 & 0.788 & $\begin{array}{l}1.128 \\
(0.467-2.724)\end{array}$ & 2.534 & 0.066 & ND & -1.253 & 0.387 & $\begin{array}{l}1.413 \\
(0.643-3.099)\end{array}$ & 0.623 & 0.176 \\
\hline (rs8099917) & & & & & & & & & & & \\
\hline
\end{tabular}

ND: no data.

Table 5 Association between SNPs and HBeAg seroconversion using logistic regression model

\begin{tabular}{|c|c|c|c|c|c|c|c|c|c|}
\hline \multirow[t]{2}{*}{ SNP (ID) } & \multicolumn{3}{|c|}{ Dominant model } & \multicolumn{3}{|c|}{ Recessive model } & \multicolumn{3}{|c|}{ Genotype model } \\
\hline & & $P$ value & OR $(95 \% \mathrm{Cl})$ & & $P$ value & OR $(95 \% \mathrm{Cl})$ & & $P$ value & OR $(95 \% \mathrm{Cl})$ \\
\hline \multirow[t]{2}{*}{ IL-10-819 (rs1800871) } & $\mathrm{CT}+\mathrm{CC} / \mathrm{TT}$ & 0.810 & $\begin{array}{l}0.912 \\
(0.428-1.941)\end{array}$ & $\mathrm{CC} / \mathrm{TT}+\mathrm{CT}$ & 0.820 & $\begin{array}{l}1.120 \\
(0.424-2.953)\end{array}$ & $\mathrm{CT} / \mathrm{TT}$ & 0.909 & $\begin{array}{l}0.852 \\
(0.369-1.970)\end{array}$ \\
\hline & & & & & & & $\mathrm{CC} / \mathrm{TT}$ & & $\begin{array}{l}1.042 \\
(0.368-2.948)\end{array}$ \\
\hline \multirow[t]{2}{*}{ IL-10-592 (rs1800872) } & $C A+C C / A A$ & 0.885 & $\begin{array}{l}1.058 \\
(0.497-2.252)\end{array}$ & $C C / A A+C A$ & 0.160 & $\begin{array}{l}1.905 \\
(0.768-4.726)\end{array}$ & CA/AA & 0.306 & $\begin{array}{l}0.754 \\
(0.313-1.814)\end{array}$ \\
\hline & & & & & & & CC/AA & & $\begin{array}{l}1.696 \\
(0.638-4.504)\end{array}$ \\
\hline \multirow[t]{2}{*}{ HLA-DPA1 (rs3077) } & $\mathrm{TC}+\mathrm{TT} / \mathrm{CC}$ & 0.070 & $\begin{array}{l}2.016 \\
(0.940-4.323)\end{array}$ & $\mathrm{TT} / \mathrm{CC}+\mathrm{TC}$ & 0.257 & $\begin{array}{l}3.429 \\
(0.3457-33.999)\end{array}$ & $\mathrm{TC} / \mathrm{CC}$ & 0.141 & $\begin{array}{l}1.897 \\
(0.872-4.127)\end{array}$ \\
\hline & & & & & & & $\pi / C C$ & & $\begin{array}{l}4.636 \\
(0.454-47.397)\end{array}$ \\
\hline \multirow[t]{2}{*}{ HLA-DPB1 (rs9277535) } & $A G+A A / G G$ & 0.510 & $\begin{array}{l}0.777 \\
(0.366-1.650)\end{array}$ & $\mathrm{AA} / \mathrm{GG}+\mathrm{AG}$ & 0.761 & $\begin{array}{l}0.855 \\
(0.309-2.362)\end{array}$ & $\mathrm{AG} / \mathrm{GG}$ & 0.805 & $\begin{array}{l}0.780 \\
(0.338-1.799)\end{array}$ \\
\hline & & & & & & & $\mathrm{AA} / \mathrm{GG}$ & & $\begin{array}{l}0.770 \\
(0.263-2.256)\end{array}$ \\
\hline \multirow[t]{2}{*}{ HLA-DQB2 (rs7453920) } & $\mathrm{GA}+\mathrm{AA} / \mathrm{GG}$ & 0.459 & $\begin{array}{l}1.495 \\
(0.514-4.352)\end{array}$ & $\mathrm{AA} / \mathrm{GG}+\mathrm{GA}$ & 0.304 & $\begin{array}{l}1.779 \\
(0.587-5.395)\end{array}$ & $\mathrm{GA} / \mathrm{GG}$ & ND & ND \\
\hline & & & & & & & $A A / G G$ & & ND \\
\hline \multirow[t]{2}{*}{ HLA-DQB1 (rs2856718) } & $\mathrm{GA}+\mathrm{GG} / \mathrm{AA}$ & 0.736 & $0.872(0.392-1938)$ & $\mathrm{GG} / \mathrm{AA}+\mathrm{GA}$ & 0.636 & $\begin{array}{l}1.270 \\
(0.471-3.422)\end{array}$ & GA/AA & 0.782 & $\begin{array}{l}0.80 \\
(0.343-1.863)\end{array}$ \\
\hline & & & & & & & GG/AA & & $\begin{array}{l}1.111 \\
(0.365-3.380)\end{array}$ \\
\hline \multirow[t]{2}{*}{ IL-28B (rs8099917) } & $\mathrm{GT}+\mathrm{GG} / \mathrm{TT}$ & 0.789 & $\begin{array}{l}1.128 \\
(0.467-2.724)\end{array}$ & $\mathrm{GG} / \mathrm{TT}+\mathrm{GT}$ & ND & ND & $\mathrm{GT} / \mathrm{TT}$ & ND & ND \\
\hline & & & & & & & $\mathrm{GG} / \mathrm{TT}$ & & ND \\
\hline
\end{tabular}


seroconversion group $(\mathrm{N}=43)$ ). Although the odds ratio showed a high value for a few SNPs, the difference was not significant. We thought that the statistical power was insufficient due to the small sample size. Therefore, we added the patients with late $\mathrm{HBeAg}$-seroconversion $(\mathrm{N}=16)$ to the "no HBeAg-seroconversion group". Accordingly, G2 $(\mathrm{N}=57)$ was defined as the "late or no $\mathrm{HBeAg-seroconversion} \mathrm{group".} \mathrm{Although} \mathrm{the} \mathrm{HLA-DPA1}$ (rs3077) SNP did not show a statistically significant association with early spontaneous $\mathrm{HBeAg}$ seroconversion, this study showed that the HLA-DPA1 (rs3077) SNP displayed a low p-value to have early spontaneous $\mathrm{HBeAg}$ seroconversion in children. This finding is consistent with the results of previous studies that have reported that genetic variants of $H L A-D P$ are strongly associated with the outcomes of HBV infection in Asian adult populations $[12,13,18]$. The genetic variants of $H L A-D P$ loci contribute to the risk of persistent $\mathrm{HBV}$ infection. The $\mathrm{T}$ alleles of rs3077 (HLA-DPA1) and rs9277535 (HLA-DPB1) are associated with a decreased risk of chronic HBV infection $[12,13,15,17,21,25]$. However, the assertion that these genetic variants are strongly associated with disease progression and HCC development in adults is controversial $[16-18,20]$. Hu et al. showed that HLA-DPA1 rs3077 is significantly associated with persistent HBV infection and HCC development [17]. In contrast, several studies have reported that there is no significant association between HLA-DP variants and HCC development [16,18,20]. The association between $H L A-D P$ variants and HBeAg seroconversion has not been investigated in adult populations. Although a statistically significant association was not observed, our findings indicate that the minor $\mathrm{T}$ allele for rs3077 might increase the likelihood of early spontaneous HBeAg seroconversion in children. The sample size was estimated by the software G*Power 3.1.9.2, considering the effect size 0.3 , the minimum power 0.80 , and $\alpha=0.05$, resulting in 143. However, this study evaluated 109 patients. Greater statistical power might be needed to detect a significant association between $H L A-D P$ genetic variants and early spontaneous $\mathrm{HBeAg}$ seroconversion.

IL10 promoter and IL28B polymorphisms have been reported to be associated with HBV infection control $[5,6,26]$. Genetic variants of the $I L-10$ gene promoter (IL-10-819 and -592) were associated with disease progression in adult patients with chronic HBV infection [5]. In addition, genetic variants of the $I L-10$ gene promoter (IL-10-592) were associated with a higher risk of persistent HBV infection in adults [6]. A pediatric study in Taiwan demonstrated that the IL-10-1082 genotype GG and $I L-12-10993$ genotype CG, which influence the serum levels of IL-10 and IL-12, were associated with early spontaneous HBeAg seroconversion [8]. However, this study failed to reveal a significant association between early $\mathrm{HBeAg}$ seroconversion and cytokine genetic variants.
Interactions among HLA-restricted T lymphocytes, antibody-secreting B lymphocytes, natural killer cells, and cytokines influence the immune response to HBV infection. The effective presentation of viral antigens to CD4+ T cells and CD8+ T cells by HLA class II and class I molecules, respectively, plays a crucial role in the immune response to HBV [1,11]. Both HLA-DP and $H L A-D Q$ encode class II molecules that have been implicated in the response to HBV infection. Although the associations of HLA alleles with the outcomes of HBV infection and responsiveness/non-responsiveness to the $\mathrm{HB}$ vaccine have been evaluated in numerous studies for two or three decades [27], information in children is limited [11]. The associations of HLA with vertical transmission (DRB1*03) [28], intrauterine transmission $(D R B 1 * 11)$ [29], and responsiveness to the vaccine (DRB1*01, DRB1*03, DRB1*11, DRB1*15, and DQB1*02) $[30,31]$ have been tested in infants and children in several studies. A previous study in Taiwan showed that HLAB61 and HLA-DQB1*0503 are associated with early spontaneous $\mathrm{HBeAg}$ seroconversion in children with chronic HBV infection [32].

HLA-DPA1 and -DPB1 are less polymorphic than HLA-DR or -DQ, and the HLA-DP cell surface expression levels are likely to also be lower [33,34]. Historically, this finding led to the notion that DP may have less clinical impact than another HLA. Therefore, the HLA-DP genes have not attracted a great deal of attention by researchers compared with $H L A-D R$ and $-D Q$. Although hematopoietic stem cell transplantation [35-37], kidney transplantation [38,39], juvenile idiopathic arthritis [40], and chronic beryllium disease $[41,42]$ have been reported to be related to HLA-DP after 2000, HLA-DP had never been investigated for its relationship with HBV disease before a GWAS study identified the close association between HLA-DP and HBV infection in Asians. Although the mechanism of the influence of the HLA-DPA1 gene on HBV infection outcomes remains unclear, a recent study demonstrated that HLA-DPA1 mRNA expression was found in normal liver and that the rs3077-G genotype decreased mRNA expression [43]. The decreased mRNA expression might be related to the risk of persistent HBV infection.

Of the 7 SNPs, 2 did not conform to HWE. No occurrence of mutations, no natural selection pressure, a large sample size, and random selection are required to test for HWE $[44,45]$. However, this was a retrospective study, and the sample size was small. A majority of the children were referred to our hospitals from small hospitals or private clinics because of a failure to prevent mother-to-child transmission or the elevation of serum transaminases during follow-up. To collect samples for the G2 group, $37 \mathrm{HBV}$ carrier mothers were enrolled as convenience samples in this study. Therefore, there was 
a significant difference in the sex ratio between the G1 and G2 groups. At the same time, 2 mother-child pairs and 3 sibling pairs were involved in this study. These conditions might contribute to the lack of HWE in the present study.

There are several limitations in this study. Multivariate analysis showed that there was a statistical significance in gender, duration of the follow-up period, serum HBV DNA levels, and transmission route between G1 and G2. Obviously, patient selection bias caused the significance difference in gender and duration of the follow-up period. Because it was impossible to examine serum HBV DNA levels at initial visit, serum HBV DNA levels at last visit were measured. Therefore, gender, duration of the follow-up period, and serum HBV DNA levels were not considered to be predictors for early $\mathrm{HBeAg}$ seroconversion. Although the source of HBV infection was unknown in $16(28 \%)$ of 57 patients with late or no $\mathrm{HBeAg}$ seroconversion, multivariate analysis showed that mother-to-child transmission was a risk factor for late or no HBeAg seroconversion. This finding is consistent with previous studies, which reported that mother-to-child transmission mode is an important factors affecting HBeAg clearance rate in chronic HBV infection [46,47]. In addition, pregnant women were also enrolled in G2, though the follow-up duration of pregnant mothers was shorter than children. As it was difficult to recruit $\mathrm{HBeAg}$-seroconversion-negative patients in the pediatric department, to enroll a sufficient number of $\mathrm{HBeAg}$ seroconversion-negative patients in this study, we recruited pregnant mothers. These factors might influence the results of this study.

\section{Conclusions}

The HLA-DPA1 SNP rs3077 showed a low p-value, but not significant, to have early spontaneous HBeAg seroconversion in children. This genetic variant might be a useful factor in the decision to treat children with chronic HBV infection.

\footnotetext{
Abbreviations

HBV: Hepatitis B virus; HCC: Hepatocellular carcinoma; HLA: Human leukocyte antigen; IL28B: Interleukin 28 B; SNPs: Single-nucleotide polymorphisms.
}

\section{Competing interests}

The authors declare that they have no competing interests.

\section{Authors' contributions}

HK contributed to the design of this study and drafted this manuscript. JM, $\mathrm{Al}, \mathrm{T}, \mathrm{TS}, \mathrm{AT}$, and TF participated in data collection and critically revised the manuscript. All the authors concurred with the submission and take responsibility for the manuscript. All authors read and approved the final manuscript.

\section{Acknowledgement}

This study was supported by the Nukada scholarship fund and grants from the Ministry of Health, Labour, and Welfare, Japan.

\section{Author details}

'Department of Pediatrics, Toho University, Sakura Medical Center, 564-1 Shimoshizu Sakura, Chiba 285-8741, Japan. ²Division of Hepatology and Gastroenterology, Department of Pediatrics, Eastern Yokohama Hospital, Yokohama, Japan. ${ }^{3}$ Division of Pediatrics and Perinatology, Faculty of Medicine, Tottori University, Yonago, Japan.

Received: 16 June 2014 Accepted: 24 October 2014

Published: 6 November 2014

\section{References}

1. Kao JH, Chen DS: Global control of hepatitis B virus infection. Lancet Infect Dis 2002, 2:395-403.

2. Sokal EM, Paganelli M, Wirth S, Socha P, Vajro P, Lacaille F, Kelly D, MieliVergani G: Management of chronic hepatitis B in childhood: ESPGHAN clinical practice guidelines: consensus of an expert panel on behalf of the European Society of Pediatric Gastroenterology, Hepatology and Nutrition. J Hepatol 2013, 59:814-829.

3. El-Serag HB: Epidemiology of viral hepatitis and hepatocellular carcinoma. Gastroenterology 2012, 142:1264-1273 e1261.

4. Chu CM, Liaw YF: Chronic hepatitis B virus infection acquired in childhood: special emphasis on prognostic and therapeutic implication of delayed HBeAg seroconversion. J Viral Hepat 2007, 14:147-152.

5. Miyazoe S, Hamasaki K, Nakata K, Kajiya Y, Kitajima K, Nakao K, Daikoku M, Yatsuhashi H, Koga M, Yano M, Eguchi K: Influence of interleukin-10 gene promoter polymorphisms on disease progression in patients chronically infected with hepatitis B virus. Am J Gastroenterol 2002, 97:2086-2092.

6. Cheong JY, Cho SW, Hwang IL, Yoon SK, Lee JH, Park CS, Lee JE, Hahm KB, Kim JH: Association between chronic hepatitis B virus infection and interleukin-10, tumor necrosis factor-alpha gene promoter polymorphisms. J Gastroenterol Hepatol 2006, 21:1163-1169.

7. Du T, Guo XH, Zhu XL, Li JH, Lu LP, Gao JR, Gou CY, Li Z, Liu Y, Li H: Association of TNF-alpha promoter polymorphisms with the outcomes of hepatitis B virus infection in Chinese Han population. J Viral Hepat 2006, 13:618-624.

8. Wu JF, Wu TC, Chen $\mathrm{CH}, \mathrm{Ni}$ YH, Chen HL, Hsu HY, Chang MH: Serum levels of interleukin-10 and interleukin-12 predict early, spontaneous hepatitis B virus e antigen seroconversion. Gastroenterology 2010, 138:165-172 e161-163.

9. Wu JF, Ni YH, Lin YT, Lee TJ, Hsu SH, Chen HL, Tsuei DJ, Hsu HY, Chang MH: Human interleukin-10 genotypes are associated with different precore/ core gene mutation patterns in children with chronic hepatitis $B$ virus infection. J Pediatr 2011, 158:808-813.

10. Xia Q, Zhou L, Liu D, Chen Z, Chen F: Relationship between TNF- < alpha $>$ gene promoter polymorphisms and outcomes of hepatitis B virus infections: a meta-analysis. PLoS One 2011, 6:e19606.

11. Chatzidaki V, Kouroumalis E, Galanakis E: Hepatitis B virus acquisition and pathogenesis in childhood: host genetic determinants. J Pediatr Gastroenterol Nutr 2011, 52:3-8

12. Kamatani $Y$, Wattanapokayakit S, Ochi H, Kawaguchi T, Takahashi A, Hosono N, Kubo M, Tsunoda T, Kamatani N, Kumada H, Puseenam A, Sura T, Daigo Y, Chayama K, Chantratita W, Nakamura Y, Matsuda K: A genome-wide association study identifies variants in the HLA-DP locus associated with chronic hepatitis B in Asians. Nat Genet 2009, 41:591-595.

13. Mbarek H, Ochi H, Urabe Y, Kumar V, Kubo M, Hosono N, Takahashi A, Kamatani Y, Miki D, Abe H, Tsunoda T, Kamatani N, Chayama K, Nakamura Y, Matsuda K: A genome-wide association study of chronic hepatitis $B$ identified novel risk locus in a Japanese population. Hum Mol Genet 2011, 20:3884-3892

14. Guo X, Zhang Y, Li J, Ma J, Wei Z, Tan W, O'Brien SJ: Strong influence of human leukocyte antigen (HLA)-DP gene variants on development of persistent chronic hepatitis B virus carriers in the Han Chinese population. Hepatology 2011, 53:422-428.

15. Wang L, Wu XP, Zhang W, Zhu DH, Wang Y, Li YP, Tian Y, Li RC, Li Z, Zhu X, Li JH, Cai J, Liu L, Miao XP, Liu Y, Li H: Evaluation of genetic susceptibility loci for chronic hepatitis B in Chinese: two independent case-control studies. PLoS One 2011, 6:e17608

16. Li J, Yang D, He Y, Wang M, Wen Z, Liu L, Yao J, Matsuda K, Nakamura Y, Yu J, Jiang $X$, Sun S, Liu Q, Jiang $X$, Song Q, Chen M, Yang H, Tang F, Hu X, Wang J, Chang Y, He X, Chen Y, Lin J: Associations of HLA-DP variants 
with hepatitis B virus infection in southern and northern Han Chinese populations: a multicenter case-control study. PLoS One 2011, 6:e24221.

17. Hu L, Zhai X, Liu J, Chu M, Pan S, Jiang J, Zhang Y, Wang H, Chen J, Shen H, $\mathrm{Hu}$ Z: Genetic variants in human leukocyte antigen/DP-DQ influence both hepatitis $B$ virus clearance and hepatocellular carcinoma development. Hepatology 2012, 55:1426-1431.

18. Nishida N, Sawai H, Matsuura K, Sugiyama M, Ahn SH, Park JY, Hige S, Kang JH, Suzuki K, Kurosaki M, Asahina Y, Mochida S, Watanabe M, Tanaka E, Honda M, Kaneko S, Orito E, Itoh Y, Mita E, Tamori A, Murawaki Y, Hiasa Y, Sakaida I, Korenaga M, Hino K, Ide T, Kawashima M, Mawatari Y, Sageshima $M$, Ogasawara $Y$, et al: Genome-wide association study confirming association of HLA-DP with protection against chronic hepatitis B and viral clearance in Japanese and Korean. PLoS One 2012, 7:e39175.

19. Wong DK, Watanabe T, Tanaka Y, Seto WK, Lee CK, Fung J, Lin CK, Huang FY, Lai CL, Yuen MF: Role of HLA-DP polymorphisms on chronicity and disease activity of hepatitis B infection in Southern Chinese. PLOS One 2013, 8:e66920.

20. An P, Winkler C, Guan L, O'Brien SJ, Zeng Z: A common HLA-DPA1 variant is a major determinant of hepatitis B virus clearance in Han Chinese. J Infect Dis 2011, 203:943-947.

21. Cheng HR, Liu CJ, Tseng TC, Su TH, Yang HI, Chen CJ, Kao JH: Host genetic factors affecting spontaneous $\mathrm{HBsAg}$ seroclearance in chronic hepatitis $B$ patients. PLoS One 2013, 8:e53008.

22. Sasieni PD: From genotypes to genes: doubling the sample size. Biometrics 1997, 53:1253-1261.

23. Faul F, Erdfelder E, Lang AG, Buchner A: G*Power 3: a flexible statistical power analysis program for the social, behavioral, and biomedical sciences. Behav Res Methods 2007, 39:175-191.

24. Kotlowski R, Bernstein CN, Silverberg MS, Krause DO: Population-based case-control study of alpha 1-antitrypsin and SLC11A1 in Crohn's disease and ulcerative colitis. Inflamm Bowel Dis 2008, 14:1112-1117.

25. Hu Z, Liu Y, Zhai X, Dai J, Jin G, Wang L, Zhu L, Yang Y, Liu J, Chu M, Wen J, Xie K, Du G, Wang Q, Zhou Y, Cao M, Liu L, He Y, Wang Y, Zhou G, Jia W, Lu J, Li S, Liu J, Yang H, Shi Y, Zhou W, Shen H: New loci associated with chronic hepatitis B virus infection in Han Chinese. Nat Genet 2013, 45:1499-1503.

26. Seto WK, Wong DK, Kopaniszen M, Proitsi P, Sham PC, Hung IF, Fung J, Lai CL, Yuen MF: HLA-DP and IL28B polymorphisms: influence of host genome on hepatitis $B$ surface antigen seroclearance in chronic hepatitis B. Clin Infect Dis 2013, 56:1695-1703.

27. Singh $R$, Kaul $R$, Kaul A, Khan K: A comparative review of HLA associations with hepatitis $B$ and $C$ viral infections across global populations. World J Gastroenterol 2007, 13:1770-1787.

28. Liu HY, Kong BH, Luo X, Xu YP, Dai MS, Jiang S: Study on the association between maternal-infantile vertical transmission of hepatitis $B$ virus and human leukocyte antigen DR gene domain. Zhonghua Fu Chan Ke Za Zhi 2003, 38:599-603.

29. $X u$ YY, Yu JY, Zhong YW, Song HB, Liu HH, Jia LL, Li SL, Xu JQ, Li Q: Association between the frequency of class II HLA antigens and the susceptibility to intrauterine infection of hepatitis B virus. Int J Biol Sci 2008, 4:111-115.

30. Hohler T, Reuss E, Evers N, Dietrich E, Rittner C, Freitag CM, Vollmar J, Schneider PM, Fimmers R: Differential genetic determination of immune responsiveness to hepatitis $B$ surface antigen and to hepatitis $A$ virus: a vaccination study in twins. Lancet 2002, 360:991-995.

31. Martinetti M, De Silvestri A, Belloni C, Pasi A, Tinelli C, Pistorio A, Salvaneschi L, Rondini G, Avanzini MA, Cuccia M: Humoral response to recombinant hepatitis B virus vaccine at birth: role of HLA and beyond. Clin Immunol 2000, 97:234-240.

32. Wu JF, Chen $\mathrm{CH}$, Hsieh RP, Shih HH, Chen YH, Li CR, Chiang CY, Shau WY, Ni $\mathrm{YH}$, Chen HL, Hsu HY, Chang MH: HLA typing associated with hepatitis B $E$ antigen seroconversion in children with chronic hepatitis $B$ virus infection: a long-term prospective sibling cohort study in Taiwan. J Pediatr 2006, 148:647-651.

33. Edwards JA, Durant BM, Jones DB, Evans PR, Smith JL: Differential expression of HLA class II antigens in fetal human spleen: relationship of HLA-DP, DQ, and DR to immunoglobulin expression. J Immunol 1986, 137:490-497.

34. Guardiola J, Maffei A: Control of MHC class II gene expression in autoimmune, infectious, and neoplastic diseases. Crit Rev Immunol 1993, $13: 247-268$.
35. Zino E, Frumento G, Marktel S, Sormani MP, Ficara F, Di Terlizzi S, Parodi AM, Sergeant R, Martinetti M, Bontadini A, Bonifazi F, Lisini D, Mazzi B, Rossini S, Servida P, Ciceri F, Bonini C, Lanino E, Bandini G, Locatelli F, Apperley J, Bacigalupo A, Ferrara GB, Bordignon C, Fleischhauer K: A T-cell epitope encoded by a subset of HLA-DPB1 alleles determines nonpermissive mismatches for hematologic stem cell transplantation. Blood 2004, 103:1417-1424.

36. Shaw BE, Potter MN, Mayor NP, Pay AL, Smith C, Goldman JM, Prentice HG, Marsh SG, Madrigal JA: The degree of matching at HLA-DPB1 predicts for acute graft-versus-host disease and disease relapse following haematopoietic stem cell transplantation. Bone Marrow Transplant 2003, 31:1001-1008.

37. Fleischhauer $K$, Shaw BE, Gooley T, Malkki M, Bardy P, Bignon JD, Dubois V Horowitz MM, Madrigal JA, Morishima Y, Oudshoorn M, Ringden O, Spellman S, Velardi A, Zino E, Petersdorf EW, International Histocompatibility Working Group in Hematopoietic Cell Transplantation: Effect of T-cell-epitope matching at HLA-DPB1 in recipients of unrelated-donor haemopoietic-cell transplantation: a retrospective study. Lancet Oncol 2012, 13:366-374.

38. Singh P, Colombe BW, Francos GC, Martinez Cantarin MP, Frank AM: Acute humoral rejection in a zero mismatch deceased donor renal transplant due to an antibody to an HLA-DP alpha. Transplantation 2010, 90:220-221

39. Thaunat $\mathrm{O}$, Hanf W, Dubois V, McGregor B, Perrat G, Chauvet C, Touraine JL, Morelon E: Chronic humoral rejection mediated by anti-HLA-DP alloantibodies: insights into the role of epitope sharing in donor-specific and non-donor specific alloantibodies generation. Transpl Immunol 2009, 20:209-211.

40. Hollenbach JA, Thompson SD, Bugawan TL, Ryan M, Sudman M, Marion M, Langefeld CD, Thomson G, Erlich HA, Glass DN: Juvenile idiopathic arthritis and HLA class I and class II interactions and age-at-onset effects. Arthritis Rheum 2010, 62:1781-1791.

41. Fontenot AP, Torres M, Marshall WH, Newman LS, Kotzin BL: Beryllium presentation to CD4+ T cells underlies disease-susceptibility HLA-DP alleles in chronic beryllium disease. Proc Natl Acad Sci U S A 2000, 97:12717-12722

42. Lombardi G, Germain C, Uren J, Fiorillo MT, du Bois RM, Jones-Williams W, Saltini C, Sorrentino R, Lechler R: HLA-DP allele-specific T cell responses to beryllium account for DP-associated susceptibility to chronic beryllium disease. J Immunol 2001, 166:3549-3555.

43. O'Brien TR, Kohaar I, Pfeiffer RM, Maeder D, Yeager M, Schadt EE, Prokunina-Olsson L: Risk alleles for chronic hepatitis $B$ are associated with decreased mRNA expression of HLA-DPA1 and HLA-DPB1 in normal human liver. Genes Immunol 2011, 12:428-433.

44. Lotsch J: Basic genetic statistics are necessary in studies of functional associations in anesthesiology. Anesthesiology 2007, 107:168-169. author reply 169.

45. Vermehren J, Lotsch J, Susser S, Wicker S, Berger A, Zeuzem S, Sarrazin C, Doehring A: A common HLA-DPA1 variant is associated with hepatitis B virus infection but fails to distinguish active from inactive Caucasian carriers. PLoS One 2012, 7:e32605.

46. Chang MH, Sung JL, Lee CY, Chen CJ, Chen JS, Hsu HY, Lee PI, Chen DS: Factors affecting clearance of hepatitis $B$ e antigen in hepatitis $B$ surface antigen carrier children. J Pediatr 1989, 115:385-390.

47. Kim HS, Kim HJ, Shin WG, Kim KH, Lee JH, Kim HY, Jang MK: Predictive factors for early $\mathrm{HBeAg}$ seroconversion in acute exacerbation of patients with HBeAg-positive chronic hepatitis B. Gastroenterology 2009, 136:505-512.

\section{doi:10.1186/1756-0500-7-789}

Cite this article as: Komatsu et al:: Association between singlenucleotide polymorphisms and early spontaneous hepatitis B virus e antigen seroconversion in children. BMC Research Notes 2014 7:789. 